\title{
FAMILY LIFE CRISIS - A COMBINATION OF TRADITIONAL AND POSTMODERN VALUES AND FORMS OF LIFE
}

\author{
Hermína Mareková ${ }^{1}$
}

\begin{abstract}
In the recent times, we are witnessing turbulent changes in society which cannot be avoided, even by families. These changes began to manifest themselves most markedly at the end of World War I and became more pronounced in the second half of the 20th century. A diverse range of cohabitation forms has emerged. Discussions about these forms have multiplied, with new questions arising. There is still a debate among experts about what form of cohabitation is called "family". Is the family still considered the foundation of the state, the basic building block of society? Despite these shifts in cohabitation, we still consider the family the most stable institution in society. The older functions that the family has fulfilled so far are gradually changing as a result of the current societal changes, and divisions exist only in theoretical considerations. When examining crisis in the family, the position of women in the family is also an important aspect, especially when regarding gender equality. Few studies address the issue that "women's thinking" about the family depends on the myriad of external and internal conditions that women encounter in childhood and during their upbringing. We later transfer these "inner truths" into our behavior when we are adults.

We cannot ignore the importance of mass media, such as TV, the Internet, the various world communication networks, which are regarded by contemporary sociology as the third factor of socialization, alongside the family and school. Unfortunately, these may be regarded as rather as a factor of negative socialization.
\end{abstract}

UDC Classification: 304, DOI: https://doi.org/10.12955/pss.v2.228

Keywords: family, values, crisis, functions

\section{Introduction}

Families have not escaped the turbulent changes in society. Despite certain shifts in cohabitation, we still consider the family to be the most stable institution in society, even though sociologists have different views and questions, such as: whether the family is still considered the foundation of the state, the basic building block of society?

There is still a debate among researchers about what form of cohabitation we call "family".

Andorka (2003) states that what we call the family is a small cohabiting group, in which members are bound by blood relations (marriage or origin). A more "modern" understanding is used by Giddens (2006) and Somlai (2013), who no longer tie the family exclusively to blood relations, but rather regard every atypical cohabitation as a family, such as a single-parent family, a mosaic family, but also the cohabitation of homosexual partners (Mareková, 2019).

The ancient functions that the family has performed so far are gradually changing as a result of current changes in society, and the divisions of family functions now only exist in older theories.

One of the reasons for these changes is that in societies before industrialization, production was concentrated within the extended family and after industrialization, production moved outside the family, outside the household, even though there is still a non-negligible number of domestically produced things, e.g. agricultural products, house construction, etc. Consumption, to a greater extent, has remained in the family. Expectations from a few decades ago about exclusive public catering have not been fulfilled.

The family still keeps one of the most important functions expected by society, namely the socialization of its offspring. Its importance has even increased. In the pedagogical literature, we encounter the opinion that the school's participation in the upbringing of young ones has already significantly diminished. Even the influence of the extended family, which had previously been actively involved in upbringing, has decreased. Where it cannot be effectively represented by the family, the role is taken over by various groups on the streets, namely so-called gangs. Similarly, we cannot ignore the importance of mass media, such as TV, the Internet, the various world communication networks, which are considered by contemporary sociology to be the third factor of socialization, alongside the family and school; unfortunately, these may be regarded as rather a factor of negative socialization.

Nowadays, a new term is often used: the "lifestyle" of the family. This terminology was introduced by Thorstein Veblen (1899/1966). It was even defined by the WHO in 1989 as a way of being that results

\footnotetext{
${ }^{1}$ Danubius University, Sládkovičovo, Slovakia, hermina.marekova@gmail.com
} 
from human living conditions and their impact on the environment, as well as individual patterns of behavior that result from personality traits and socio-cultural factors (Dworak, 2009).

In the area of caring for the sick and elderly, society has also failed in providing an equivalent social institution, when needed. In fact, the family is very often left to fend for itself when taking care of the sick and elderly. In recent years, there have been attempts by NGOs to fill this gap, but it is still not possible to talk about an equivalent substitute. These attempts cannot even be adequate, because, due to the gradual aging of the population, there is great demand for this service, and it has now become a profitable business.

Sociological research shows that problematic behavior, such as crimes, alcoholism, suicide, are more common in circles where people do not live in orderly relationships. We can add that the family, if it is functional (i.e. without socio-pathological phenomena) is still irreplaceable in the socialization of youth and the protection of mental health of the adults. Livingstone (2002) sees the family as a safe place for its members. However, whereas in the previous period, families at risk usually came from a socially weaker environment, nowadays families living in prosperity are also becoming ones at risk.

\section{Family crisis}

Opinions differ on the question whether the family is changing, going through a crisis, or whether we are witnessing the demise of the family (or its particular form, which we have known so far). The crisis of the family has been a recurring topic in social science circles since the 19th century.

As early as 1859, a text appeared as an article in the Boston magazine Quarterly Review, in which the author says: "Families will disappear from our Earth in the old sense, and not only our free institutions but also the bare existence of our society are in danger" (Lantz, Schultz and O'Hara, 1977). This report is often repeated in countries of the West to this day. In the 1980s, the British Conservative Party turned the family problem into a party problem. Margaret Thatcher declared at a Conservative conference in 1986 that "the basis of our policy is the family, the freedom of the family and its wellbeing." Nave-Herz (1998) stated that the expansion of industrialization, urbanization and urban poverty in cities will sooner or later lead to the breakdown and extinction of the family. Anthropologists and sociologists have begun to distinguish between different forms of the extended family (parents, grandparents, siblings) from the nuclear family (which includes children and partners) (Adams and Trost, 2005).

Sociological and other social explanations write about five thematic areas (Somlai, 2013):

1. Families have lost the economic and moral foundations of their lives.

2. The crisis is experienced by the nuclear family, i.e. the form that emerged after socioeconomic modernization.

3. Divorces break down the family.

4. The change of gender roles and the entry of women into work break down the family.

5. Family and kinship ties have weakened.

Families have lost their economic and ethical basis. The best-known theory comes from Fréderic Le Play (1903), who says in his works that the stability of the family depends on the stability and indivisibility of property. According to him, the onset of bourgeoisie resulted in the loss of male virtues, corruption and laziness in the interest of abundance (Andorka, 2003).

The crisis is rather experienced by the nuclear family: This theory was first formulated by L. H. Morgan (1870), followed by F. Engels, who said that "the couple family is a manifestation of barbarism, as the group family a manifestation of savagery and a monogamous family is a manifestation of civilization" (Engels, 1884). Later, Jack Goody, based on his research, said that there was no society in human history where the nuclear family was not important (Goody, 2000). According to Durkheim (1984), modernization and strong individualization reduced the family. $\mathrm{He}$ called such a family conjugal, which was created by reducing the "famille paternelle".

In modern sociology, Parsons (1971) says that behind the breakdown of the family is the process of modernization, industrialization, because before industrialization, the vast majority of people lived in multigenerational families. However, this theory has also been challenged by demographic research (Laslett, 1971). 
Divorce causes families to break down, such is the explanation in the "crisis" theories. They cited the increase in individualism and weakened solidarity within the family as reasons. However, such views are nothing new. As early as 1792, during the French Revolution, entering into a marriage became a social contract, thus weakening the regulatory power of religion. In the 19th and 20th centuries, bourgeois marriage and even divorce by agreement have gradually spread in Europe. Therefore, some saw the break-up of the family in allowing divorce law (e.g. Parsons, 1971), but this gives rise to the idea that until divorces were allowed, the families were functional. There is no research to confirm this theory, but it can be assumed that problems in families existed before, and it just was not possible (especially for women) to escape even from a pathological relationship.

According to some researchers, family crisis is caused by the entry of women into work and the associated change in the gender role - in the civic family, the roles were originally clearly divided and, in general, the woman took care of the household, children and family relationships. With the advent of women's work in the 20th century, this role changed, not only for women, but also for men and children (Bertram, 2000). The ongoing sexual revolution in the 1960s also contributed to these changes. In that era, various changes came to the fore. The advent of birth control pills brought about a revolution. However, these changes did not remove the patriarchal stereotype (Sas, 1984).

Since the 1970's, feminist activities have been strengthening, especially in the United States and Western Europe. There are studies monitoring the situation of women in society (gender studies, women's studies). We have been witnessing post-feminist trends since the 1990s (Ferchhoff, 1999), where women already take for granted their equality in schools and workplaces. The gradual entry of women into work is related to the entry of post-industrial society and the emergence of sectors where hard physical work was no longer necessary. However, despite efforts, women's average earnings remained lower than men's (Castells, 2006), which was also due to the fact that sectors where women were employed lagged behind in income and that men were rarely employed in these sectors (such as teaching, sales, social work). Despite emancipation efforts, according to numerous studies, the vast majority of people prefer a two-career (two-earner) household (Peuckert, 2008; Bútorová, 1996). Changes in the division of labor in families are slow.

There is a well-known study by Young and Willmott (1999) in which for a period of three years, they observed the life of London families, where the division of labor and care for the family was carried out according to traditional norms and stereotypes. In the 1960s, major changes became apparent and more or less there was an even division of household work. Such families began to be referred to as symmetrical. Later research did not confirm this finding, as $66 \%$ of all domestic work continues to be done by women. Washing, ironing, cooking and also the care of a family member - even on the male side - continue to be performed by women (asymmetrical families) (Herche, 2010).

Family and kinship relations have weakened - Parsons' modernization theory (1971) says that nuclear families have already isolated themselves from the extended family. We often also see a weakening of family solidarity. According to Šulová (2004), a malfunction in the parental role and parenthood has emerged, because parents often cannot take care of their children due to unfavorable conditions in society (war, death). Parents cannot take care of children due to their own immaturity. Parents do not want to take care of their children, and disinterest and hostility prevail. In contrast, there are also parents, who are hyper-protective of their children (helicopter parents). They are exaggeratedly protective, pampering their children and, subsequently, such individuals are not able to live independently.

This trend has occurred even among immigrants, and according to Thomas and Znaniecki (2002), the original family with its values is becoming inconvenient for young migrants; the family becomes important only in solving problems.

Nevertheless, the claim that the family is coming to an end has no basis so far. However, it should not be overlooked that there are constant and significant changes in the nature of marriage and the family, which sometimes reflect wider social changes and are sometimes even directly aided by them, but predictions of family demise appear to be unfounded. However, an individualistic lifestyle is clearly beginning to prevail, and within it, women in particular have to deal - contrary to tradition - with the dilemma between career and family. Social pressure on the individual is growing, and he/she must adapt to changed local and global situations. 
Socio-economic, political and other changes have affected not only the life of society, but also the life of families. As Beck (2004) writes, this is a postmodern situation and the detraditionalization of life forms. According to him, the solution is individual life strategies in the organization of life, but also of the family form. In 2004, he described today's society as risky for families in that "the problematic situations of a fully-realized market society cannot be managed in the social, life forms and institutional structures of a defective market society."

The family is undergoing a change from the traditional to the modern to the postmodern family and should create favorable conditions for the socialization of children. The postmodern family was first identified by Shorter (1975, in: Možný 2006, p. 232). But even in this postmodern situation, having a family is considered a value and we take it for granted.

The family in our conditions is the family of an employed woman, writes Matoušek (1997). The woman's employment is more of an economic necessity, as a family can seldom survive with a single income. The woman is overwhelmed with her career and household management and mostly also with the upbringing of her children. A woman expects from a man, among other things, material security and despite the fact that some women are successful in business, expectations from men are still traditional and conservative, according to the Institute of Sociology of the Academy of Sciences of the Czech Republic (Matoušek, 1997. S. 41).

Research on this issue takes place in other countries, but only sporadically in Slovakia. The largest research on family in the Slovak Republic, "The Contemporary Family in Slovakia" should be mentioned (Ondrejkovič et al., 2006). The current family in Slovakia has certain characteristics, but they are not spread over the entire territory. It is characteristic that there are differences between regions:

1. The economic situation is undergoing changes and we are witnessing social differentiation (a narrow group of people characterized by financial abundance and vice versa).

2. Demographic development is characterized by a decline in birth rates. The higher the degree of modernization of the country, the lower the birth rate. There is a change in value orientation, there is a lack of interest on the part of society in the value of motherhood, also due to the media, where we encounter an excessive preference for other values, in accordance with the carpe diem principle.

We are becoming a performance society. The number of children born to single mothers is growing, and the number of partnership cohabitation is increasing. All of this is becoming culturally tolerated. According to Ondrejkovič et al. (2006, p. 40): "The development of the Slovak family in the last decade reflects a mixture of historical continuity and significant changes. Even in young families (young generation) a combination of traditional and postmodern values and forms of life dominates".

To confirm these statements, it would be necessary to have more research available, where it would be possible to empirically identify and verify individual aspects of the issue, because so far, we are only inactively observing this phenomenon and without relevant data the concept of aid is ineffective.

The family reflects, directly and indirectly, on the current state of society, and according to Fukuyama (2006), all the serious problems that accompany the transformation of society in recent years (unbridled individualism, huge societal dynamics including the shift of social norms and values, considerable liberalism, consumerism etc.) have affected reproduction, family and male-female relationships to the greatest extent.

We are witnessing a dynamic transformation of society, which was apparently constantly present, but now it seems to be accelerated and we do not see clearly how and where it would be most appropriate to intervene in this development.

\section{Conclusion}

The combination of traditional and postmodern value attitudes and forms of family life have produced a very diverse range of opinions. Despite disagreements, the consensus is that more or less the socialization of a family member remains to be the most important role of the family, significantly expected in society, because in the case of social pathology in the family, the positive socialization of a family member is endangered. Discovering how to intervene in this development is still waiting for us. To confirm these statements, it would be necessary to have more research available, where it 
would be possible to empirically identify and verify individual aspects of the issues, because so far, we are only idly watching them, and without relevant data the concept of aid is ineffective, both on macro and micro levels. On the macro level, there is a lack of family social policy, while on the micro level, a lack of targeted social counseling. However, changes in this area are difficult to expect, as it is surprising that, unlike in surrounding countries, the Slovak Republic has not yet prepared a document on state family policy that would motivate young people to start a family.

\section{References}

Adams, B. N. a Trost, J. (eds.) (2005). Handbook of World Families. Thousand Oaks, etc.: Sage.

Andorka, R. (2003). Bevezetés a szociológiába. Introduction to Sociology. Budapest: Oziris.

Beck, U. (2004). Riziková společnost. Na cestě k jiné moderně. Risk Society. Towards a New Modernity. Praha: Slon.

Bertram, H. (2000). Arbeit, Familie und Bindungen. Work, Family and Ties. In: Kocka, J., Offe, -C. (Hrsg.). Geschichte und Zukunft der Arbeit. The History and Future of Work. Frankfurt am Main: Campus.

Bútorová, Z., Bosá, M., Filadelfiová, J. et al. (1996). Ona a on na Slovensku: Ženský údel očami verejnej mienky. She and He in Slovakia. Gender Issues in Public Opinion. Focus.

Castells, M. (2006). Az identitás hatalma. The power of identity. Budapest: Gondolat kiadó.

Durkheim, E. (1984). Erziehung, Moral und Gesellschaft. Education, Morality and Society. Lecture at the Sorbonne. Frankfurt am Main, cit. Baumgart, F. (Hrsg.). Theorien der Sozialisation. Bad Heilbrunn: Klinkhardt.

Dworak, A. (2009). Rodina a životni styl-perspektiva sociální pedagogiky. Family and Lifestyle - The Perspective of Social Pedagogy. In: Sociální pedagogika ve střední Evropě - současný stav a perspektivy. Sborník z medzinárodní konference. Social Pedagogy in Central Europe - Current State and Perspectives. Proceedings from an International Conference. Brno: IMS.

Engels, F. (1970). A család, a magántulajdon és az állam eredete. The Origin of the Family, Private Property and the State. Budapest: Kossuth könyvkiadó.

Ferchhoff, W. (1999). Jugend an der Wende vom 20. zum 21. Jahrhundert. Youth at the Turn of 20th to 21st Century. Opladen: Leske und Budrich.

Fromm, E. (1997). Anatomie lidské destruktivity. The Anatomy of Human Destructiveness. Praha: NLN.

Fukuyama, F. (2006). Vel'ký rozvrat. The Great Disruption. Praha: Academia.

Giddens, A. (2006). Sociology. Fifth Edition. Cambrige: Polity Press.

Goody, J. (2000). The European Family. Oxford: Malden (Mass): Blackwell.

Herche, V. (2010). Háztartási munkamegosztás - Azonosságok és külömbségek Európában. Domestic division of labor. Similarities and differences in Europe. Demografia. 53. (1.)

Lantz, H., Schultz, M. a O'Hara, M. (1977). The Changing American Family From the Pre-Industrial Period: A Final Report. American Sociological Rewiev, 42. In: Giddens, A. 1993. Sociology. Cambrige: Polity Press.

Laslett, P. a Wall, R. (eds.) (1972). Household and Family in Past Time. Cambridge. Cambrigde UP. In: ANDORKA, R., 2003. Bevezetés a szociológiába. Introduction to Sociology. Budapest. Oziris.

Laslett, P. (1971). The World we have lost. England before the Industrial Age. London: Charles Scribner's Son.

Le Play, F. (1903). A munkásviszonyok reformja. The Reform of Labor Relations. Budapest: Magyar Tudományos Akadémia.

Livingstone, S. (2002). Young People and New Media. London: Sage.

Mareková, H. (2019). Premeny rodiny v čase. Kultúrno-historické paralely. Transformations of the Family over Time. Cultural-Historical Parallels. Brno: MSD.

Matoušek, O. (1997). Rodina jako instituce a vzt'ahová sit'. The Family as an Institution and a Relationship Network. Praha: Sociologické nakladatelství (SLON).

Morgan,L.H. (1870). Systems of Consanguinity and Affinity of the Human family. Washington, Smithonian Institution. In: Andorka, R. (2003). Bevezetés a szociológiába. Introduction to Sociology. Budapest: Oziris.

Možný, I. (2006). Rodina a spoločnost'. The Family and Society. Praha: Sociologické nakladatelstí.

Nave-Herz, R. (1998). Die These über den Zerfall der Familie. The Thesis About the Disintegration of the Family. In: Lepsius, M.R., Friedrichs, J. , Mayer, K.U., (Hrsg.). Die Diagnosefähigkeit der Soziologie. The Diagnosing Ability of Sociology. Wiesbaden: VS Verlag für Sozialwissenschaften . S. 288-315 (Kölner Zeitschrift für Soziologie und Sozialpsychologie, Sonderheft).

Ondrejkovič, P. et al. (2006). Rodina v novom miléniu. The Family in the New Millennium. Nitra: UKF.

Parsons, T. (1971). The system of modern societes. Englewood Cliffs. New Jersey. Prentice-Hall.

Peuckert, R. (2008). Familienformen im sozialen Wandel. Family Forms in Social Change. 7, vollst. überarb.. Aufl., Wiesbaden: Verlag für Sozialwissenschaften.

Sas, H. J. (1984). Életmód és család. Lifestyle and family. Budapest: Akadémia kiadó.

Shorter, E. (1975). The Making of the Modern Family. New York: Basic Books. 
Somlai, P. (2013). Család 2.0 - Együttélési formák a polgári családtól a jelenkorig. Family 2.0 - Forms of Cohabitation From the Bourgeois Family to the Present. Napvilág kiadó.

Šulová, L. (2004). Raný psychický vývoj ditěte. Early Mental Development of the Child. Praha: Karolinum.

Thomas, W. I. a Znaniecki, F. (2002). A Lengyel paraszt Európában és Amerikában. The Polish Peasant in Europe and In America. 1-2. Budapest: Új Mandátum kiadó.

Veblen, T. (1966). Exerpts from The Theory of the Leisure Class. pp. 36-42. In: Bendix , Lipset (eds.). Class. Status, and Power. New York: The Free Press.

Young, M. a Willmott, P. (1999). Család és rokonság Kelet-Londonban. Family and kinship in East London. Budapest: Új Mandátum kiadó. 